УДК 576.89

DOI: 10.31453/kdu.ru.978-5-7913-1143-6-2020-178-183

Коколова Людмила Михайловна Kokolova Luidmila Michailovna доктор ветеринарных наук, заведующая лабораторией гельминтологии Doctor of veterinary sciences, managing the laboratory of helmintology

Гаврильева Любовь Юрьевна Gavrilieva Lubov Yurievna кандидат ветеринарных наук, старший научный сотрудник лаборатории гельминтологии candidate of veterinary sciences, senior staff scientist of laboratory of helmintology

Сивцева Евгения Владимировна Sivtseva Evgenia Vladimirovna аспирант лаборатории гельминтологии graduate student of laboratory of helmintology Якутский научно-исследовательский институт сельского хозяйства имени М.Г. Сафронова обособленное подразделение Федерального государственного бюджетного учреждения науки Федеральный исследовательский центр «Якутский научный центр, Сибирского отделения Российской академии наук»

Романов Иван Иванович Romanov Ivan Ivanovich

Студент Student Северо-восточный Федеральный Университет

\title{
ИЗМЕНЕНИЕ КЛИМАТА И ВЛИЯНИЕ НА РАСПРОСТРАНЕНИЕ КЛИМАТОЗАВИСИМЫХ ПАРАЗИТАРНЫХ БОЛЕЗНЕЙ В ЯКУТИИ
}

\section{CLIMATE CHANGE AND THE IMPACT ON THE SPREAD OF CLIMATE- DEPENDENT PARASITIC DISEASES IN YAKUTIA}

\begin{abstract}
Аннотация. В статье излагаются отдельные аспекты возможного изменения климата и условий жизни в результате хозяйственной деятельности человека в условиях распространения многолетней мерзлоты. Особое внимание авторы исследования уделили внимание на изменении относительно паразитарных болезней, происходящих за последние годы, с которыми сталкиваются занимающиеся разведением традиционных отраслей сельского хозяйства в сельской местности. Изучая, климатозависимых болезней паразитарной
\end{abstract}


этиологии, их распространенность и природные очаги на территории Якутии вызывает большой интерес исследователей вопрос адаптации паразитов к происходящим изменениям природно-климатического характера.

Ключевые слова: мерзлота, хозяйственная деятельность, сельское поселение, климат, условия жизни, наблюдения, Якутия.

Abstract. In the article the separate aspects of possible change of climate and terms of life are expounded as a result of economic activity of man in the conditions of distribution of long-term frozen condition of ground. The special attention research authors spared attention on the change of relatively parasitogenic illnesses what be going on in the last few years with that engaging in clash breeding of traditional industries of agriculture in rural locality. Studying, climate dependent illnesses of parasitogenic etiology, their prevalence and natural hearths on territories of Yakutia for researchers large interest causes the question of adaptation of vermin to what be going on changes of natural and climatic character.

Key words: permafrost, economic activity, rural settlement, climate, living conditions, observations, Yakutia.

Со второй половины XX века многочисленными международными и российскими наблюдениями фиксируются изменения климата и зоны мерзлоты, которые в совокупности подтверждают парадигму глобального изменения климата $[1,2,3]$. Российские наблюдения показывают, что по территории России среднегодовая температура растет более чем в 2,5 раза быстрее глобальной, со скоростью $0,45^{\circ} \mathrm{C}$ за десять лет, и особенно это заметно в приполярных районах, где скорость роста температуры достигает до $0,8^{\circ} \mathrm{C}$ за 10 лет. Результаты ежегодных исследований по особенностям температурного режима и его влияния на климат показали, что с 1936 года 2016 год стал самым теплым по осредненным температурным данным по территории России среднегодовая аномалия температуры воздуха составила $+1,69^{\circ} \mathrm{C}$ [3]. Как мы видим изменение климата происходит не только в глобальном масштабе, но и, прежде всего, на региональном уровне. Якутия относится к регионам, в которых климатические изменения происходят заметно быстрее, чем в среднем на планете. Согласно данных учёных из университета Дж. Вашингтона из США прогноз изменения и критический момент будет достигнут к 2040 году [4]. На потепление климата 
наиболее остро реагируют антропогенные ландшафты, т.е. освоенные и именно в этих участках идёт деградация вечной мерзлоты, которая может нанести серьезный ущерб и сильно повлияют на хозяйственную деятельность людей, инициируют новые формы рисков, требующих принятия оперативных решений и адаптации к происходящим изменениям.

Изменение климата и восприятие происходящего оценивается зимний период: холоднее/теплее, длиннее/короче, снега стало больше/меньше, ветер стал сильнее/слабее; летний период: холоднее/теплее, длиннее/короче, дождей меньше/больше; весенний и осенний период: длиннее/короче; резкие перепады температуры уменьшились /увеличились, оттаивание вечной мерзлоты уменьшилось/увеличилось. При оценке изменений климата меняет карту распространения инфекционных и инвазионных заболеваний, уже ни у кого не вызывает удивления. Действительно, когда растет температура, и меняется влажность, меняются условия обитания различных возбудителей и их ареал. Что касается паразитарных болезней, то всегда считалось, что паразит привязан к своему хозяину независимо от условий обитания, если условия благоприятные, то паразиты могут менять своих хозяев. Это значит, что теперь распространение паразитарных болезней будет предсказать гораздо сложнее. Более того, многие болезни, которые считались редкими, с изменением климата и с переходом паразитов от одних хозяев к другим, могут стать более распространенными. В условиях потепления климата происходит изменение условий обитания и многих возбудителей инфекционных заболеваний, и это приводит к тому, что люди начинают контактировать с патогенами, к которым они чувствительны, но с которыми они никогда прежде не встречались, и к атаке которых их иммунитет просто не готов. Можно привести пример, среди нетрансмиссивных вирусных природно-очаговых зоонозов в качестве климатозависимых болезней бактериальной этиологии рассмотрены лептоспироз и туляремия. Среди трансмиссивных природно-очаговых заболеваний, пироплазмоз, северный бабезиоз, клещевой энцефалит, болезнь Лайма переносчиками, которых являются иксодовые клещи. В первую очередь, они связаны с изменениями 
климата, как наблюдаемыми ныне, так и предполагаемыми. К факторам климатического риска относятся расширение ареалов членистоногих переносчиков и повышение их численности, а также аналогичное повышение численности и расширение ареалов позвоночных, преимущественно мышевидных грызунов, являющихся резервуарами природно-очаговых инфекций и прокормителями переносчиков в природе. Потепление климата оказывает влияние на частоту распространенности природно-очаговых заболеваний, изменяя условия существования популяций переносчиков и условия развития возбудителей в переносчике, что влечет за собой изменение возможностей передачи многих болезней человека и животных, распространяющихся при посредстве членистоногих переносчиков.

Доступ к безопасной воде остается крайне важным вопросом обеспечения здоровья населения, так как по-прежнему во многих населенных пунктах в питьевой воде обнаруживаются возбудители инфекций. Особенно страдает от недостатка качественной воды население с низким подушевым доходом. В Арктическом регионе, по данным Роспотребнадзора [7], наиболее неблагополучная ситуация с качеством питьевой воды сложилась в Республике Саха (Якутия). Здесь 32\% проанализированных образцов воды из водоемов 1-й категории не отвечает гигиеническим нормативам по микробиологическим показателям, что в 1,3 раза выше среднего показателя по стране. За последние годы состояние водных объектов Республики Саха (Якутия) ухудшается. Это связано как с продолжающимся антропогенным загрязнением, так и с ежегодными природными катаклизмами в виде весенних разливов при вскрытии рек и осенних наводнений.

Результаты специального санитарно-вирусологического исследования свидетельствуют о широком распространении патогенных вирусов в водах реки Лены - основного источника питьевого водоснабжения населенных пунктов этой республики [6]. Низкое качество воды поверхностных водоисточников по санитарно-химическим показателям в местах водозабора также характерно для Республики Саха (Якутия) отличается значительным увеличением числа 
образцов воды, не соответствующих гигиеническим нормативам по микробиологическим показателям [8]. Даже после соответствующей обработки воды, в т.ч. ее дезинфекции, в водопроводной сети весьма велика доля образцов воды, не соответствующей гигиеническим нормативам по микробиологическим показателям.

Заключение Социально-экономическое развитие региона, как Республика Саха (Якутия), сильно зависит от климатических и географических факторов. Одними из первых с последствиями изменения климата сталкиваются коренные жители республики, занимающиеся традиционным сельским хозяйством, проживающие в сельской местности. В арктических и северных районах, всегда четко можно наблюдать за изменениями, происходящими в природе, так как от этого напрямую зависит хозяйственная деятельность. При освоении новых участков под и промышленную добычу алмазов и золота приводит к упадку сельского хозяйства, имеется опасность попадания возбудителя заболевания в организм и животных, возрождения природных очагов опасных инфекций и инвазий. Эта опасность более всего возрастает в засушливые годы, когда животные при пастьбе вытаптывают пастбища, оголяется почвенный покров. Воздействие потепления можно оценить увеличением количества возбудителей климатозависимых паразитарных болезней, для сокращения поступления инвазий необходимо создать единую эпизоотоло-эпидемиологическую базу данных по особоопасным антропозоонозам общих для человека и животных.

\section{Библиографический список}

1. IPCC Climate Change 2014: Impacts, Adaptation, and Vulnerability. Pt B: Regional Aspects // Contribution of Working Group II to the Fifth Assessment Report of the Intergovernmental Panel on Climate Change. Cambridge, United Kingdom and N.Y., N.Y., USA, Cambridge Univ. Press, 2014, 688 p.

2. Доклад об особенностях климата на территории Российской Федерации за 2015 год. М., Росгидромет, 2016. 68 с. 
3. Доклад об особенностях климата на территории Российской Федерации за 2016 год. М., Росгидромет, 2017.-70 с.

4. Shiklomanov N. I., Streletskiy D. A., Swales T. B., Kokorev V. A. Climate Change and Stability of Urban Infrastructure in Russian Permafrost Regions: Prognostic Assessment based on GCM Climate Projections // Geographical review. Volume 107, Issue 1. January 2017. Р. 125-142. Анисимов О. А., Шерстюков А. Б. Оценка роли природно-климатических факторов в изменениях криолитозоны России // Криосфера Земли. 2016. Т. ХХ. № 2. С. 90-99.

5. Карпов В.С., Чернявский В.Ф., Каратаева Т.Д. Основные зооантропонозы в Якутии (эпизоотология и эпидемиология). - Якутск, 1997 г., $154 \mathrm{c}$.

6. Коколова Л.М., Романов И.И. Требования к составу и свойствам воды используемой для рыбохозяйственных целей в условиях регионов с повышенным уровнем естественных радионуклидов. / Ж. МААО Вып. № 42 (2018) Том 2. С.18-22.

7. Эколого-эпидемиологическая оценка качества воды реки Лена /Савилов Е.Д., Долженко Ю.А., Протодьяконов А.П. и др.- Новосибирск: Наука, 2006 г., $136 \mathrm{c}$.

8. Протодьяков А.П. Эпидемиологические и организационные основы системы мероприятий по обеспечению санитарно-эпидемиологического благополучия населения в период ликвидации последствий наводнений (на модели наводнения 2001 г. в г. Ленске): Автореф. дис., докт. мед. наук, 2007, М. 